\title{
The Effect of Relative Age on Some Performance Characteristics in Young Volleyball Players
}

\author{
Cengiz Akarçeşme ${ }^{1}$, Sinem Hazır Aytar ${ }^{2}$ \\ ${ }^{1}$ Faculty of Sport Sciences, Gazi University, Ankara, Turkey \\ ${ }^{2}$ Faculty of Health Sciences, Depatment of Sports Sciences, Başkent University, Ankara, Turkey \\ Correspondence: Cengiz Akarçeşme, Faculty of Sport Sciences, Gazi University, Ankara, Turkey.
}

Received: August 8, 2018

doi:10.11114/jets.v6i11.3607
Online Published: September 6, 2018

URL: https://doi.org/10.11114/jets.v6i11.3607

\begin{abstract}
It has been evaluated in the literature that different maturation levels exist in the same chronological age and this may be an advantage for athletic performance. The aim of this study was to examine the performance characteristics of young male and female volleyball players in the same chronological age according to their relative age.

A total of 536 athletes who were 14 years old and similar training age, 238 male and 298 female subjects participated in this study. Relative age was determined by quitting the quartile of the year starting from January. Explosive strength (counter movement and squat jumps), anaerobic strength and capacity (Wingate test), aerobic capacity (20m shuttle run) and speed $(5 \mathrm{~m}$ and $10 \mathrm{~m}$ sprint) were measured. 2x4 ANOVA was used to determine the differences between gender and relative age groups, and Bonferroni test was used to determine the differences between the quarters of the year. The significance level of all statistical procedures was accepted as 0.05 .

The distribution of volleyball players in the quarters was $47.9 \%, 27.7 \%, 17.6 \%, 6.7 \%$ for males, $39.9 \%, 29.5 \%, 17.4 \%$ and $13.1 \%$ for females respectively. The differences between the genders in all variables were statistically significant $(\mathrm{p}<0.05)$. Relative age effect (RAE) was not significant in all variables examined as performance parameters $(\mathrm{p}>0.05)$.

As a result of this study it was found that both female and male volleyball players were mostly born in the first quarter of the year. On the other hand, relative age was not a distinctive effect on performance variables of young volleyball players in the same chronological age.
\end{abstract}

Keywords: volleyball, relative age, chronological age, performance characteristics

\section{Introduction}

Several studies have been conducted especially in the field of education to investigate the effect of the quarter of the year in which an individual was born. Afterwards, these researches started to gain a great significance in sports (Larouche, Laurencelle, Grondin, \& Trudeau, 2010; Nakata \& Sakamoto, 2012). In order to ensure that they have equal opportunities for success in their active ages, teachers and coaches tend to separate children into groups according to their chronological age (Sierra-Diaz, Gonzalez-Villora, Pastor-Vicedo, \& Serra-Olivares, 2017; Vincent \& Glamser, 2006). This grouping was made to minimize the possible emotional and physical differences of children (Okazaki, Keller, Fontana, \& Gallagher, 2011). There is enough evidence that being a few months older than their peers is advantageous in acquiring academic achievements (Vincent \& Glamser, 2006). In those countries in which the sports age is accepted as January 1, children born in January are 11 , months older than children born in December (Delorme, Boiche, \& Raspaud, 2009). For this reason, it is considered that early-born children are more advantageous than late-borns by age of competition (Okazaki et al., 2011). The first studies on Relative Age Effect (RAE) on sports were related to elite ice hockey players, which was conducted in 1984 (Thompson, Barnsley, \& Battle, 2004). Teams are frequently divided into groups within the same year and January 1 is considered to be the beginning of such grouping (Sierra-Diaz et al., 2017). September 1 is considered as the beginning in such countries as the UK (Cobley, Baker, Wattie, \& McKenna, 2009; Pekel \& Kamis, 2018). In Japan, April 1 is considered to be the beginning and March 31 is the end (Nakata \& Sakamoto, 2012).

There is no significance of such fixed dating as a month or a day (Pekel \& Kamis, 2018). Children born in the first two quarters of the year were found to be more advantageous in the same type of study than those who were born in the last two quarters of the year (Cobley et al., 2009; Sierra-Diaz et al., 2017). Besides, those who were born later developed 
late (Delorme, Chalabaev, \& Raspaud, 2011). Especially during the developmental periods (13-15 for males and 12-14 for females), physical differences are at the highest level (Cobley et al., 2009).

According to some researchers, there is evidence that relatively older students receive higher grades in physical education. The overrepresentation of relatively older players in youth sport has been attributed to the physical advantages associated with advanced maturation (Reed, Parry, \& Sandercock, 2017).

The RAE can be observed in the discrepancies that exist in academic attainment, lifelong earnings, self- esteem, and well- being, according to individuals' birth date. In sport, the RAE describes "The relationship observed between an individual's month of birth relative to their peers and their achievement in sports (Reed et al., 2017). Relative age can be associated with several features such as strength, endurance and sport-related technique (Cobley et al., 2009; Delorme, Boiche, \& Raspaud, 2010; Mulazimoglu, Bayansalduz, Kaynak \& Mulazimoglu, 2016; Sierra-Diaz et al., 2017). It is quite significant particularly in the branches in which body size, power and strength are very important (Cobley et al., 2009). However, this case seems to decrease after puberty (Patalay et al., 2015; Sierra-Diaz et al., 2017). Hancock et al. proposed an integrated theoretical model to explain the RAE in sport in which relatively older children's success in sport is a combination of the initial advantages of being older (Matthew Effect) combined with the higher expectation of others (Pygmalion effect) and of themselves (Galatea effect) (Hancock, Adler, \& Cote, 2013).

There is strong evidence that all three effects play a role in educational RAEs, but the roles these social agents play in schools sports have not been investigated (Reed et al., 2017). A number of studies have investigated the relationship between relative age and gender, but their results differ. There were no significant differences in relative age for some studies in girls, whereas others found no significant differences. Given the fact that the relative age status of girls and boys in the same branch is different, the fact that the sport is more popular on a gender side may also affect the situation (Nakata \& Sakamoto, 2012). On the other hand, the fact that girls reach adolescence earlier in terms of physical and biological maturation can cause a difference between girls and boys (Delorme et al., 2009; Nakata \& Sakamoto, 2012).

Girls who are in the early adolescence period tend to quit the performance sport more often than those who reach adolescence late (Delorme et al., 2009). Some studies have claimed that the RAE is more effective than gender differences. In other words, the biggest female athletes born in the same year were performing better than the youngest men. RAE in males is more than females. The RAE varies according to sports branches. In a study on women athletes aged 8-16 years in England, it was determined that $50 \%$ of the selected tennis and swimmers were born in the first three months of the year. In the same study, however, gymnasts were seen to be distributed neatly throughout the year. It is thought that adolescence is advantageous for gymnastics (Vincent \& Glamser, 2006).

The difference in pre-adolescent motor skills in men and women is minimal. There is also a linear development until adolescence. During adolescence, the increase in testosterone hormone results in a larger and leaner body mass for men, and thus leading to the development of the cardiovascular system, which helps develop motoric features such as strength, endurance and speed. In females, the transition to adolescence has a number of physiological factors that restrict performance compared to males (Vincent \& Glamser, 2006). In literature, RAE in different sports branches (Sierra-Diaz et al., 2017) and volleyball were investigated, but there were no sufficient studied which examined the effect of relative age on performance parameters. Therefore, the purpose of this study is to investigate the gender differences in the effects on relative performance characteristics of elite male and female volleyball players in the same chronological age.

\section{Method}

Study Group: This study was conducted with the following subjects: 238 male (age: 179,0 $06,6 \mathrm{~cm}$; body weight: 64,9 $\pm 8,4$ $\mathrm{kg}$ ), 298 female (height: $173,1 \pm 4,7 \mathrm{~cm}$, body weight: 60,2 $\pm 7,3 \mathrm{~kg}$ ), a total of 536 volleyball players participated. Male and female athletes had similar training age $(3,85 \pm 1,45$ years and $3,77 \pm 1,31$ years, respectively). The birth dates which were collected from the athletes for the relative age were examined by dividing the 3 months of the year equally.

The measurements were conducted on two separate days; on the first day jumps, speed and anaerobic power and capacity tests were conducted during the morning and afternoon sessions, and aerobic endurance test was conducted on the second day. Data collection process was conducted according to the guidelines of the Declaration of Helsinki for human experimentation.

Jumping Tests: Squat jump and counter movement jump tests were measured by means of the Optojump system (Microgate, Italy). The tests were performed in accordance with Bosco protocol (Bosco, Luhtanen, \& Komi, 1983). Before the tests, the athletes performed a general warm-up and then the tests were conducted. Two trials were performed for both jumps and were the best scores were included.

Speed Tests: The speed performance of the athletes was measured telemetrically through a two-port photocell electronic stopwatch system (Prosport Timer, Turkey), which was placed at 5 and 10 meters. The athletes warmed up before the tests. For the statistical calculations, the best scores obtained at the end of 3 trials were assessed.

Anaerobic Power and Capacity Test: In order to determine the anaerobic strength and capacity, a Wingate test was 
conducted to athletes in the cycling ergometer (814E, Sweden) with a Monark brand, a crested type and an optical tour counter. Athletes started testing at $60-70 \mathrm{~W}$ at $60-70 \mathrm{rpm}$ for 5 minutes after warming. At the end of the warming, the calculated load $(75 \mathrm{gr} / \mathrm{kg})$ was placed on the scale and the athletes were asked to reach the maximum pedal speed within 4 seconds and the resistance resulted from the weight was reflected to the driver. With the start of the test, each athlete tried to keep the speed of the pedal as fast as possible for 30 seconds and was verbally motivated during the test (Dotan, 2006). The anaerobic strength obtained from the first 5-second period of the test and the anaerobic capacity obtained during the test are shown as W. $\mathrm{kg}^{-1}$.

Aerobic Test (Shuttle Run): A $20 \mathrm{~m}$ Shuttle Test was performed to determine the aerobic endurance of the athletes. This test was conducted with a $20 \mathrm{~m}$ track running at an increasing speed (shuttle). Each athlete was asked to perform shuttles as many as possible. Athletes set the running speed according to the sound signals from a computer programmed device (Prosport Timer, Turkey). The athletes were supposed to complete a $20 \mathrm{~m}$ track between the two signals. There was a critical line in one meter on either side of the $20 \mathrm{~m}$ track, when the athlete fails to catch a critical line in two consecutive signals, the test was terminated and the number of shuttles the athlete performed until then was recorded and used for statistical processing.

Data Analysis: Percentage distributions for quarter of the year were calculated for relative age. The mean and standard deviation values of all the parameters examined were calculated via the tables. For the variables examined, 2 x 4 (gender $\mathrm{x}$ relative age) two way variance analyses and Bonferroni test were used to determine the difference between gender and relative age groups after normality tests. The significance level of all statistical procedures was accepted as 0.05 .

\section{Results}

In this study; it was found that female and male volleyball players were born in the first quarter of the year had high percentages (47.9\% and $39.9 \%$ respectively). The distribution to other quarters of the year showed a decreasing tendency in both genders (Table 1).

Table 1. Distribution of the birth dates of female and male volleyball players according to quarters of the year

\begin{tabular}{lllll}
\hline \multirow{2}{*}{ Relative Age } & $\begin{array}{l}\text { Male } \\
\text { n }\end{array}$ & \multicolumn{3}{c}{ Female } \\
& n & \% \\
\hline Jan-Feb-Mar & 114 & 47,9 & 119 & 39,9 \\
Apr-May-Jun & 66 & 27,7 & 88 & 29,5 \\
Jul-Augu-Sep & 42 & 17,6 & 52 & 17,4 \\
Oct-Nov-Dec & 16 & 6,7 & 39 & 13,1 \\
Total & 238 & 100 & 298 & 100 \\
\hline
\end{tabular}

Male volleyball players exhibited significantly higher values than female volleyball players in all of the performance variables examined $(\mathrm{p}<0.05)$. RAE and gender*relative age interaction were not statistically significant for all variables $(\mathrm{p}>0.05)$

Table 2. Mean and standard deviation values of performance parameters of male and female volleyball players according to quarters of the year

\begin{tabular}{|c|c|c|c|c|c|c|c|c|c|c|}
\hline \multirow{2}{*}{ Variables } & \multicolumn{5}{|l|}{ Male } & \multicolumn{5}{|l|}{ Female } \\
\hline & $\begin{array}{l}\text { Jan-Feb } \\
\text {-Mar }\end{array}$ & $\begin{array}{l}\text { Apr-Ma } \\
\text { y-Jun }\end{array}$ & $\begin{array}{l}\text { Jul-Aug } \\
\text {-Sept }\end{array}$ & $\begin{array}{l}\text { Oct-No } \\
\text { v-Dec }\end{array}$ & Total & $\begin{array}{l}\text { Jan-Feb } \\
\text {-Mar }\end{array}$ & $\begin{array}{l}\text { Apr-Ma } \\
\text { y-Jun }\end{array}$ & $\begin{array}{l}\text { Jul-Aug } \\
\text {-Sept }\end{array}$ & $\begin{array}{l}\text { Oct-No } \\
\text { v-Dec }\end{array}$ & Total \\
\hline Squat Jump (cm) & $30,4 \pm 5,4$ & $29,8 \pm 4,8$ & $29,8 \pm 3,5$ & $\begin{array}{l}29,3 \pm 5 \\
6\end{array}$ & $\begin{array}{l}30,1 \pm \\
4,9\end{array}$ & $26,4 \pm 4,9$ & $27,2 \pm 4,9$ & $26,5 \pm 5,5$ & $\begin{array}{l}25,1 \pm 5, \\
1\end{array}$ & $\begin{array}{l}28,1 \pm \\
5,3\end{array}$ \\
\hline Counter Movement & & & & $33,0 \pm 5$ & $33,5 \pm$ & & & & $27,4 \pm 5$ & $30,9 \pm$ \\
\hline Jump (cm) & $34,0 \pm 6,1$ & $33,3 \pm 4,8$ & $33,0 \pm 3,8$ & 9 & 5,4 & $28,6 \pm 5,4$ & $29,4 \pm 5,2$ & $29,0 \pm 6,2$ & 1 & 5,9 \\
\hline $\begin{array}{l}\text { Anaerobic Powe } \\
\text { (W/kg) } \\
\text { Anaerobic }\end{array}$ & $9,6 \pm 1,3$ & $9,5 \pm 1,0$ & 9 & ,2 & $\begin{array}{l}9,6 \pm 1, \\
2 \\
7,6 \pm 0,\end{array}$ & , 2 & , 0 & , 2 & $7,9 \pm 1,0$ & $\begin{array}{l}7,9 \pm 1, \\
1 \\
6,2 \pm 0,\end{array}$ \\
\hline Capacity (W/kg) & $7,7 \pm 0$ & $7,7 \pm 0$ & $7,6 \pm 0$ & $7,2 \pm 0$ & 8 & $6,2 \pm 0$ & $6,3 \pm 0,8$ & $6,1 \pm 0,7$ & $6,3 \pm 0,6$ & 7 \\
\hline $5 \mathrm{~m}(\mathrm{sec})$ & $\begin{array}{l}1,017 \pm 0, \\
069\end{array}$ & $\begin{array}{l}1,019 \pm 0 \\
062\end{array}$ & $\begin{array}{l}1,015 \pm 0 \\
049\end{array}$ & $\begin{array}{l}1,028 \pm 0 \\
, 073\end{array}$ & $\begin{array}{l}1,01 \pm \\
0,06\end{array}$ & $\begin{array}{l}1,092 \pm 0, \\
117\end{array}$ & $\begin{array}{l}1,094 \pm 0, \\
153\end{array}$ & $\begin{array}{l}1,047 \pm 0, \\
108\end{array}$ & $\begin{array}{l}1,112 \pm 0 \\
, 137\end{array}$ & $\begin{array}{l}1,08 \pm \\
0,13\end{array}$ \\
\hline $10 \mathrm{~m}(\mathrm{sec})$ & $\begin{array}{l}1,809 \pm 0, \\
145\end{array}$ & $\begin{array}{l}1,803 \pm 0 \\
081\end{array}$ & $\begin{array}{l}1,803 \pm 0, \\
077\end{array}$ & $\begin{array}{l}1,828 \pm 0 \\
, 121\end{array}$ & $\begin{array}{l}1,81 \pm \\
0,12\end{array}$ & $\begin{array}{l}1,933 \pm 0, \\
144\end{array}$ & $\begin{array}{l}1,924 \pm 0, \\
158\end{array}$ & $\begin{array}{l}1,918 \pm 0, \\
129\end{array}$ & $\begin{array}{l}1,959 \pm 0 \\
, 094\end{array}$ & $\begin{array}{l}1,93 \pm \\
0,14\end{array}$ \\
\hline Number of Shuttle & $\begin{array}{l}79,0 \pm 14, \\
0\end{array}$ & $\begin{array}{l}81,5 \pm 13 \\
9\end{array}$ & $\begin{array}{l}83,4 \pm 13, \\
1\end{array}$ & $\begin{array}{l}79,9 \pm 18 \\
, 0\end{array}$ & $\begin{array}{l}80,5 \pm \\
14,1\end{array}$ & $\begin{array}{l}53,9 \pm 10, \\
7\end{array}$ & $\begin{array}{l}55,9 \pm 13, \\
5\end{array}$ & $\begin{array}{l}51,5 \pm 12, \\
8\end{array}$ & $\begin{array}{l}52,9 \pm 9, \\
4\end{array}$ & $\begin{array}{l}54,0 \pm \\
11,9\end{array}$ \\
\hline
\end{tabular}




\section{Discussion}

In this study, relative age distribution of male and female volleyball players in the same chronological age and RAE in some performance parameters were investigated. It was found that the athletes in both genders were predominantly born in the first quarter of the year, but the relative age was not significant on the performance parameters examined.

Reed and his colleagues (Reed et al., 2017) investigated the relative age of athletes aged between 11 and 18 participating in the London Youth Games. 28.48\% of female volleyball players participating in the study $(\mathrm{n}=316)$ were born in the first quarter, $24.37 \%$ in the second quarter, $25.32 \%$ in the third quarter and $21.84 \%$ in the fourth quarter. As for male volleyball players $(\mathrm{n}=324), 35.19 \%$ were born in the first quarter, $22.22 \%$ in the second quarter, $19.44 \%$ in the third quarter and $23.15 \%$ in the fourth quarter.

In the study conducted by Mulazimoglu (Mulazimoglu, Bayansalduz, Kaynak \& Mulazimoglu, 2016), Turkish Football Federation affiliated league in which they are born in the first quarter of $48.22 \%$ of the players who played in the U14 category, indicated that $10.96 \%$ of them were born in the last quarter of the year, The ratios of 14-year-old soccer players who were born in January and December were found to be statistically significant.

Women reaching the late adolescence period usually have a more ectomorphic, linear physical structure, a long leg and consequently a narrow hip and lower fat tissue. On the contrary, the opposite physical structure is observed in women reaching early puberty (Vincent \& Glamser, 2006).

Delorme at al.,(Delorme et al., 2010) investigated the relative ages of the girls who participated in the competition until they were 14 years old. In this study, the proportion of athletes born in the first quarter was $25.82 \%$, while the proportion of athletes born in the last quarter was $22.42 \%$.

Nakata \& Sakamoto (Nakata \& Sakamoto, 2012) investigated the relative age status of volleyball players in Japan's top league. 138 female volleyball players and 133 male volleyball players participated in the study. In Japan, the beginning of sporting age is accepted as April $1^{\text {st }}$ and end March $31^{\text {st }} .33 .3 \%$ of female volleyball players were born in the first quarter, $34.8 \%$ in the second quarter, $15.9 \%$ in the third quarter and 15.9 in the fourth quarter. A statistically significant difference was found in these data ( $\mathrm{p}<0.001)$. There was no statistically significant difference in males.

Delorme et al. (Delorme et al., 2009) investigated the effect of relative age on French elite volleyball players. There was no evidence of RAE on volleyball men.

The majority of the studies investigating the effect of relative age have been conducted on men, yet few studies have been conducted on women. Delorme and Raspaud (Delorme \& Raspaud, 2009) investigated the RAE on female basketball players between the ages of 7-17 years, and analyzed the results of 107,101 subjects in this context. Although the subject group is large, it is seen that there are significant differences between them when four quarters are examined. Those who were in first quarter constituted $26.1 \%$, those who were second quarter $27.4 \%$, those who were third quarter constituted $24.6 \%$ and those who were fourth quarter constituted $21.9 \%$.

In the study conducted by Vincent \& Glamser (Vincent \& Glamser, 2006) on footballers in the Under-17 Olympic Development Program, they found 25.5\% birth rate in the first quarter of the year, 26.2\% in the second quarter, 25.2\% in the third quarter and $23 \%$ in the fourth quarter. These results are not statistically significant.

In the study conducted by Pekel \& Kamış (Pekel \& Kamis, 2018) they investigated the effect of relative age on athletes who were under 14 years of age. In the study performed on 748 athletes ( 455 female, 293 male), there were differences in frequencies and percentages between the athletes born in the first quarter of the year and the athletes born in the last quarter of the year in male and female athletes, and this difference was found to be statistically significant.

Anaerobic and aerobic characteristics, speed and physical performance in women show stagnation at ages 12-13, which is very early compared to the men of their age. Therefore, physical differences begin to emerge in the female and male athletes of these ages. Women's early adolescence, which can be between 13 and 14 years of age, also reduces the performance gap between men and their peers. Female athletes reaching late adolescence often have lower performance than adolescents with early puberty (Vincent \& Glamser, 2006).

In the current study, male players showed higher values than females in all performance characteristics.

The speed test gives an idea as to whether the athlete's basic speed characteristics are developed in a sport that requires very sudden and explosive action such as volleyball. When taken together with the jump tests, the athlete can provide important information about the potential and training status. For this reason, the speed values obtained within a short distance should be regarded as important for volleyball. Male athletes are significantly faster than female athletes.

Similarly, in the anaerobic power and capacity values, the performance of male athletes is significantly higher than that of female athletes. In general, the ability of athletes to have anaerobic power at international level for anaerobic power-requiring movements, as well as their ability to sustain anaerobic movements that require frequent maximum 
violence in long-running training and competition environments, needs to be improved.

The aerobic endurance of the athletes was tested with a shuttle run. In this test, the maximum oxygen consumption $\left(\mathrm{VO}_{2} \mathrm{max}\right)$ of the athlete could be calculated as an estimate, but the high shuttle count could be considered as high $\mathrm{VO}_{2} \mathrm{max}$. This criterion is one of the most important ones in the development of endurance and in the capacity of the athlete to train. Rapid recovery among loads in the long run, long-term high-pitched performance depends on the oxygen consumption capacity developed at a certain level.

This can be explained by the change in fat and muscle mass during the developmental stages of male and female volleyball players, as well as by the differences in the training methods performed.

As a result, $47.9 \%$ of the 238 male volleyball players constituting the research universe were born in the first quarter, $27.7 \%$ in the second quarter, $17.6 \%$ in the third quarter and $6.7 \%$ in the fourth quarter. $39.9 \%$ of 298 female volleyball players were born in the first quarter, $29.5 \%$ in the second quarter, $17.4 \%$ in the third quarter and $13 \%$ in the fourth quarter. When the individual genders were taken into account, it is observed that the highest frequency is in the first quarter and the lowest frequency is in the last quarter in both male and female. As a reason for this can be shown that January 1 is regarded as sport age in Turkey. Based on the same hypothesis, the decrease in frequency seen in the last quarter of men and women can be explained.

A possible explanation may be that RAE has been observed in sports in which body size and strength play a key role. Thus, in the early levels of selection, relatively older athletes may be favored because of their advantages in height and strength. During the stages of childhood and adolescence, a more advanced biological maturation state has advantages in Different physical and physiological characteristics, e.g., body composition, fat -free mass, aerobic power, strength, endurance and speed (Campos, Stanganelli, Rabelo, Campos, \& Pellegrinotti, 2016).

An important result of the research is to determine 14 years old male and female volleyball players have significant effect on performance characteristics of relative age. However, conducting the study with different age groups, the investigation of the RAE in different sexes will shed light on the sport sciences.

\section{References}

Campos, F. A. D., Stanganelli, L. C. R., Rabelo, F. N., Campos, L. C. B., \& Pellegrinotti, İ. L. (2016). The Relative Age Effect in Male Volleyball Championships. International Journal of Sports Science, 6(3), 116-120. doi:10.5923/j.sports.20160603.08

Cobley, S., Baker, J., Wattie, N., \& McKenna, J. (2009). Annual Age-Grouping and Athlete Development A Meta-Analytical Review of Relative Age Effects in Sport. Sports Medicine, 39(3), $235-256$. https://doi.org/10.2165/00007256-200939030-00005

Delorme, N., Boiche, J., \& Raspaud, M. (2009). The Relative Age Effect in Elite Sport: The French Case. Research Quarterly for Exercise and Sport, 80(2), 336-344. https://doi.org/10.1080/02701367.2009.10599568

Delorme, N., Boiche, J., \& Raspaud, M. (2010). Relative age effect in female sport: a diachronic examination of soccer players. Scandinavian Journal of Medicine \& Science in Sports, 20(3), 509-515. https://doi.org/10.1111/j.1600-0838.2009.00979.x

Delorme, N., Chalabaev, A., \& Raspaud, M. (2011). Relative age is associated with sport dropout: evidence from youth categories of French basketball. Scandinavian Journal of Medicine \& Science in Sports, 21(1), 120-128. https://doi.org/10.1111/j.1600-0838.2009.01060.x

Delorme, N., \& Raspaud, M. (2009). The relative age effect in young French basketball players: a study on the whole population. Scandinavian Journal of Medicine \& Science in Sports, 19(2), 235-242. https://doi.org/10.1111/j.1600-0838.2008.00781.x

Hancock, D. J., Adler, A. L., \& Cote, J. (2013). A proposed theoretical model to explain relative age effects in sport. European Journal of Sport Science, 13(6), 630-637. https://doi.org/10.1080/17461391.2013.775352

Nakata, H., \& Sakamoto, K. (2012). Sex Differences in Relative Age Effects among Japanese Athletes. Perceptual and Motor Skills, 115(1), 179-186. https://doi.org/10.2466/10.05.17.PMS.115.4.179-186

Okazaki, F. H. A., Keller, B., Fontana, F. E., \& Gallagher, J. D. (2011). The Relative Age Effect Among Female Brazilian Youth Volleyball Players. Research Quarterly for Exercise and Sport, 82(1), 135-139. https://doi.org/10.1080/02701367.2011.10599730

Mulazimoglu, O., Bayansalduz, M., Kaynak, K., \& Mulazimoglu, H. D. (2016). Relative age effect in Turkish soccer. Turkish Journal of Sport and Exercise, 18(1), 64-69. https://doi.org/10.15314/tjse.14670 
Patalay, P., Belsky, J., Fonagy, P., Vostanis, P., Humphrey, N., Deighton, J., \& Wolpert, M. (2015). The Extent and Specificity of Relative Age Effects on Mental Health and Functioning in Early Adolescence. Journal of Adolescent Health, 57(5), 475-481. https://doi.org/10.1016/j.jadohealth.2015.07.012

Pekel, H. A., \& Kamis, O. (2018). Relative Age Effect on U14 Track and Field Athletes. Gazi Journal of Physical Education and Sport Sciences, 23(2), 153-162.

Reed, K. E., Parry, D. A., \& Sandercock, G. R. H. (2017). Maturational and social factors contributing to relative age effects in school sports: Data from the London Youth Games. Scandinavian Journal of Medicine \& Science in Sports, 27(12), 2070-2079. https://doi.org/10.1111/sms.12815

Sierra-Diaz, M. J., Gonzalez-Villora, S. G., Pastor-Vicedo, J. C., \& Serra-Olivares, J. (2017). Soccer and Relative Age Effect: A Walk among Elite Players and Young Players. Sports, 5(1). https://doi.org/10.3390/sports5010005

Thompson, A. H., Barnsley, R. H., \& Battle, J. (2004). The relative age effect and the development of self-esteem. Educational Research, 46(3), 313-320. https://doi.org/10.1080/0013188042000277368

Vincent, J., \& Glamser, F. D. (2006). Gender differences in the relative age effect among US Olympic Development Program youth soccer players. Journal of Sports Sciences, 24(4), 405-413.

https://doi.org/10.1080/02640410500244655

\section{Copyrights}

Copyright for this article is retained by the author(s), with first publication rights granted to the journal.

This is an open-access article distributed under the terms and conditions of the Creative Commons Attribution license which permits unrestricted use, distribution, and reproduction in any medium, provided the original work is properly cited. 